\title{
Travel and Imperialist Nostalgia in Ernest Hemingway's Green Hills of Africa
}

https://doi.org/10.33806/ijaes2000.22.1.9

\author{
Ahmad Qabaha \\ An-Najah National University, Palestine
}

Received on 23.3.2021 Accepted on 26.8.2021 Published on 1.1.2022

\begin{abstract}
This paper examines the politics of travel and imperialist nostalgia in Ernest Hemingway's memoir Green Hills of Africa. Informed by recent theoretical contributions to travel and postcolonial studies, this paper investigates ways in which the representation of travel and nostalgia in this memoir speaks to the colonial and imperialist rhetoric. Unlike previous studies, this paper suggests that the travels and nostalgia of Hemingway for Green Hills of Africa reflect certain ideological and historical determinants of the interwar politics that dominated modern American literature. While Hemingway seems to distance himself from the rhetoric of the empire, his reflections on travelling in Africa and his nostalgia for it are arguably entangled by it. This paper demonstrates that Hemingway's narrative extends a dichotomy between the East and West constructed by $19^{\text {th }}$ century (American) orientalist travel writers and critiqued by Edward Said.
\end{abstract}

Key words: Hemingway, imperialist, modern, nostalgia, politics, travel

"It always seemed stupid to be white in Africa" (Hemingway, 1956: 251)

"To be a European or an American in the Orient meant and means being aware that one belongs to a power with definite interests in the Orient" (Said, 1978: 11).

\section{Introduction}

Colonialism is not a modern phenomenon; global history is full of examples of countries that have been involved in dominating, subjugating and exploiting a foreign land and its native inhabitants. Think, for instance, of European powers that colonized, in modern history, the Americas, most of Asia, Africa, the Middle East and Oceania. These colonial experiences have demonstrated that colonialism is a structure through which the empire subordinates another territory, while claiming its superiority and supremacy. Colonialism is a combination of territorial, linguistic, cultural, political, epistemic and economic domination of one nation by another. This domination is facilitated and reinforced by textual practices, which are literary imaginations.

Literature either consolidates the empire or resists it; it is either colonial or postcolonial. As Elleke Boehmer (2005: 1) argues, "if it is agreed that the history of the world for the past few centuries has been profoundly shaped by colonial interests, then there is a sense in which much of the literature produced during that time can be said to be colonial or postcolonial, even if only tangentially so". In this 
sense, colonial literature exhibits colonial perceptions, motifs and ethos introduced by metropolitan authors and participated in and reinforced these experiences. According to Boehmer (2005: 2), colonial texts "contributed to the complex of attitudes that made imperialism seem part of the order of things". By contrast, postcolonial literature "sets out in one way or another to resist colonialist perspectives" as well as challenging "the discourses which supported colonization-the myths of power, the race classifications, the imagery of subordination" (Boehmer, 2005: 3). Postcolonial literature contests colonial power and its legacies. As Edward Said's Orientalism (1978) and Culture and Imperialism (1993) generally suggest, textual and cultural representations were vital to the process of imagining and colonizing others' lands, and, conversely, supporting decolonization from the colonizer.

The domination over a territory or a nation aimed not only to impose political or economic authority; it wanted also to exert imaginative power. The idea is that colonial and postcolonial literature "contributed to the making, definition, and clarification of those same preoccupations" (Boehmer, 2005, 5). This is much evident in the $1^{\text {st }}$ half of the $20^{\text {th }}$ century during which postcolonial nationalist writers accentuated the aspirations of their colonized countries, whereas Western writers, who travelled to the Third World, "were growing more confident and assertive" in their nationalist perceptions and depictions of once colonized nations (Boehmer, 2005: 95).

Typical of modernists, most of Hemingway's work accounts for his experiences of travelling away from the US, especially to Africa. Hemingway (1899-1961) was born and raised in Oak Park, Illinois. He was a prominent American travel and expatriate novelist, short-story writer and journalist who reported the atrocities of World War I. He wrote numerous works of fiction and non-fiction, many of which are seen as classics of American literature, and were written abroad. According to Harry Levin, "most of Hemingway's fiction, which the world accepts as the exemplification of a strenuous Americanism, takes place on foreign soil. This transatlantic impetus reached its fullest intensity with the artistic movement that surfaced after the first World War" (1970: xi). In 1921, Hemingway joined the expatriate community in Paris, and he made a major contribution to their Modernist thought. Because Hemingway's works are politically charged, and he participated in World War I, his expatriate oeuvre should be situated within a framework that attends to the political and imperialist implications it embeds. While Hemingway travelled to all continents, Hemingway's choice of Africa is worth investigating since Hemingway's depiction of Africa reflects the historical and ideological determinants of the time. According to Edward Said, all texts are worldly, and they reflect the historical circumstances and realities out of which they emerged. Said writes that "texts have ways of existing that even in their most rarefied form are always enmeshed in circumstance, time, place, and society — in short, they are in the world, and hence worldly" (1983: 35). Said's contribution to literature and humanities is highly influential, but it is perhaps the link he makes between humanities and politics what impelled scholars' critical analysis of the travel of Western authors to the orient, and in this case Africa. 
Hemingway's work under study is much more than a work about big game hunting during the safaris the author took with his wife Pauline Marie Pfeiffer. It is about travelling and representing British colonial Africa and its people through a racial and imperialist lens.

Although Hemingway's work is over studied by critics, his reflections on Africa, especially in Green Hills of Africa, are relatively neglected. Philip H. Melling (2006), for example, explores the representation of cultural imperialism in Hemingway's The Old Man and the Sea. Richard Fantina (2005) studies Hemingway's cultural affiliation to the Africans during his safaris in 1953, and his interest in cross-dressing and Africanizing himself. Yet, the author focuses on his experiments with gender transformation while staying in Africa, and his perception of Africa as a primitive arena in which he acts his sexual fantasies. The author explores Hemingway's identification with British colonialism during his safaris, yet he does not focus his analysis on Green Hills of Africa. Guy Reynolds (2008: 4) argues that Hemingway's posthumous non-fiction novel Under Kilimanjaro "seems to be a text more engaged with the legacy and mythology of white settler culture than a travel book [which] alert[s] to contemporary change within a late imperial order". He continues that this text marks "a historical turning-point, when empires fall, when one hegemonic force gives way to another, even though the former remains present in terms of narrative line and rhetorical impress". Miriam Mandel argues that scholarship has almost neglected the role of Africa in Hemingway's life and work. This urges her to embark on an edited collection entitled Hemingway and Africa, published in 2011. This edited collection offers a historical and biographical interpretation of Hemingway's experiences in Africa. But this project is left unfinished since it does not answer the main question it raises: why Africa, in particular, is the destination of the writer? This edited collection fails to provide a comprehensive account of the politics of Hemingway's travel in Africa and his imperialist nostalgia. Josep Armengol discusses race and gender in this memoir, arguing that whiteness and masculinity are interrelated. The author argues that around the late $19^{\text {th }}$ and early $20^{\text {th }}$ centuries, white middle-class men, in a variety of ways and contexts, tried to reinforce their masculine power by restoring to the idea of civilization and racial domination through contrasting themselves with darkskinned men. The author anticipates that Hemingway's autobiographical safari narrative depicts Africa in colonial and imperialistic terms (2011: 73). However, the critic tries to explain that by referring to the frontier myth, and romanticizing Africa as a new frontier. Inspired by recent theoretical contributions on travel and imperialist nostalgia, this article argues that Hemingway's African travel memoir reflects colonialist tendency and imperialist nostalgia. It focuses on his non-fiction book Green Hills of Africa which remains underrated. This book has preceded, and arguably informed the other works of Hemingway on Africa. Therefore, a thorough analysis of this book should yield news insights that help understand Hemingway's other African texts that came after it.

Scholarship has recently noticed a remarkable interest in travel literature, much of which has been inspired by "post-colonial" ethos. Edward Said's Orientalism has triggered the study of the ways in which explorers and colonial 
officials justified or consolidated colonialism. Said promulgated the idea that categorizing the experience of the "East" vis-à-vis the "West" as a binary opposition underpinned the structures behind Orientalism, the discourse that fabricated a production of knowledge of the "other" within the "Orient," while relegating it to an inferior status. The works of the travel writers in the modern period, in particular, have attracted critical perspectives on the link between aesthetics and politics (Clifford and Marcus, 1986: 40). A huge part of the focus of these critical inputs was on North American writers whose works seemed to justify or even consolidate the colonial project by foregrounding the "split geographies of 'us' and 'them', 'civilization' and 'barbarism', 'Good' and 'Evil'". (Gregory, 2004: 11). Many of the works of North American writers deploy protagonists who are expatriates engaging themselves in politics. Hemingway's works are exemplary of this fashion. Jake Barnes in Fiesta: The Sun Also Rises is a soldier who participated and was wounded in World War I, which makes him unable to have sex. In $A$ Farewell to Arms, lieutenant Frederic Henry, who is the novel's protagonist and narrator, is a young American ambulance driver who served in the Italian army during World War I. In "Soldier's Home", the protagonist Harold Krebs is a young man who feels unhappy upon his return home from serving in World War I. Hemingway's politically-orientated works seem to be autobiographical. His memoir Green Hills of Africa directly speaks about the documentation of Hemingway's travels in Africa in the first half of the twentieth century in ways that suggest imperialist exigencies. In like fashion to Conrad's Heart of Darkness, Hemingway's work seems a little bit problematic: its protagonist seeks to distance himself from the rhetoric of the empire, but his reflections are arguably entangled by it.

While this kind of writing has traditionally been read based on its own universal themes and aesthetic elements, they are now "read as evidence of the manner in which such ideals have served in the historical process of colonization", and ways in which they have "come into play with the establishment and maintenance of colonial authority" (Spurr, 1993: 3). This kind of travel writing has been associated with colonialism, written by travelers coming from the West to describe their experiences in the East in a manner that appeals for an audience and powers supporting colonization at home. As Mandel argues, there are some factors that impel politicizing Hemingway's African trips: they "were funded by out-side sources, both were preceded by European interludes ... [and they] produced a large body of literature, considering the relatively short time that Hemingway spent there" (2011: 17). We sense in this work certain ideological and historical determinants of the interwar politics that dominated modern American literature, much of which was written by modernist authors living away from the US. Harry Levin asserts that "most of Hemingway's fiction, which the world accepts as the exemplification of a strenuous Americanism, takes place on foreign soil", and "this transatlantic impetus reached its fullest intensity with the artistic movement that surfaced after the first World War" (1970: xi). Modern American literature has reshaped the perceptions of American audience of their own identity and their relationship with the world. Indeed, most of modern American literature was 
produced outside the US, and it was influenced by the experiences of the writers and their views of various places around the world.

US Travel and expatriate movement became popular in the late $19^{\text {th }}$ century. This movement influenced early $20^{\text {th }}$ century American Modernist authors who left the US in search of alternative forms of living, stimuli for creativity or adventure and discovery. Modern American literature was therefore influenced by the transatlantic impetus of the time. In Orientalism, Edward Said argues that U.S. and European writers who visited the orient/ Africa after the $19^{\text {th }}$ century were influenced by the colonial and imperialist interests of their countries. For Said, even the most imaginative and polemical American writers were constrained in what they could either experience or say about the orient. Said introduced in Orientalism the phrase "political knowledge" to describe how Western travelogue about the orient was put into the service of political and colonial powers (1978: 9). Literature in this way can be seen as "a political-intellectual power, wherein the nineteenthcentury authorship about the Orient was produced within a certain framework of reference that is politically oriented" (Qabaha, 2019: 1033).

Modern U.S scholarship and interest in Africa has arguably emanated from nineteenth-century orientalist perceptions of it. Hemingway states in Green Hills of Africa that all modern American literature has come from Twain's fiction which circulated orientalist conceptions and racial stereotypes about the East (2002: 23). While America was not directly involved in the colonization of Africa, Africa was affected by "the exportation of American democracy and culture to other regions of the world" (Droze, 2018). Moreover, Hemingway seems to continue the legacy of British orientalists and colonialists in Africa. As Reynolds suggests, "textual and contextual information also confirms Hemingway's deep immersion in British colonialism ... he also became an honorary British colonial official during his safari" (Reynolds, 2008: 194). Reynolds focuses his analysis on Under Kilimanjaro, suggesting that it is an American travel work written back to the British Empire, and its author places himself into "a quintessential imperialist terrain" (2008: 195).

\section{Travelling in Africa}

One striking pattern in this memoir is the constant movement of its characters during this African safari. Mandel argues that "safari is a Swahili word that means journey - is as far as one can get from the very concept of home. It is by definition composed of movement, travel, and impermanence" (2011: 18). Hemingway's protagonist displaces himself in Africa, and the movement seems permanent. Travelling and movement in this sense promises adventure, discovery, freedom and exploring the world. Hemingway in this sense represents the (American) Modernist expatriate's idea of the necessity of choosing your own place/home away from your homeland to get a sense of outsiderness, 'foreignness', or in-between-ness which allows creativity and (re)construction of a new selfhood. As Deborah L. Parsons argues, "crucial to the connotations of the (American) expatriate perspective" is that "it is a legitimated form of outsiderness" (2000: 150). In Green Hills of Africa, Hemingway describes this kind of outsiderness as intrusion. He writes that "[w]e 
are the intruders" (2002: 201). Almost most of Modernist American writers, including Hemingway, expressed their interest in alienating themselves from their culture, and they debated the notion of home and attachment. Mandel elaborates that Safari "denies not just the notion of home, but of place, even of an away place. Perhaps it is not a place at all, but a constant displacement: it represents the act of travel itself, the quintessential condition of impermanence, of departure and seeking" (2011: 19). The key words here are departure, impermanence, seeking and displacement. These key words indicate the parameters of home mapped out by Hemingway's protagonists. Place or home in Hemingway's writing can be seen as something performed and reconstructed by those inhabiting it and by their reiterative cultural, literary and daily practices. As Cresswell argues, "place is made and remade on a daily basis. Place provides a template for practice - an unstable stage for performance" (2001: 39). The rural space in this context connotes a cultural and social site that offers new modes of self-fashioning. This means the necessity of investigating the politics of travelling in Africa.

Using wider historical and cultural lenses, one can argue that there is an allusion embedded in Hemingway's representation of the virtue of travelling and the search for the green hills of Africa to the idea of America itself as a virgin place constructed on a hill. The colonization and industrialization of America was premised on myths of glorifying a foreign land /a country of plethora of natural resources, and teemed with the cult that the country would provide bountiful opportunities for both economic success and personal fulfilment - "The American Dream" (Cresswell, 2001: 20). Hemingway makes a comparison between his movement in Africa and that of his ancestors in America in terms of the possibility to achieve fulfillment and satisfaction. He describes Africa as the right place to live in since he 'felt at home' there, and he foregrounds his African experience as something different from his ancestors in America (2002: 200). While Hemingway is at pains to distance himself from the ideological concerns of the time, his representation of Africa and its people seems to prove the reverse. Cresswell argues "mobility as a geographical phenomenon in American life is linked to a number of ideological themes, including opportunity, democracy and modernity" (2001: 20). However, the story of mobility in America as a trope for opportunity, democracy and modernity does not show the other version of it. It needs to address "central stories, often untold: tales of marginality and exclusion, which cast a different light on the grand narratives of nationhood, of progress, of democracy and of modernity" $(2001,20)$. America was perceived by early settlers as a vast continent replete with natural resources that motivated citizens for movement and migration; analogously, Africa is represented in Hemingway's memoir as a colonial space, which Hemingway expresses his love for and to which he expresses his intention to return and make his home (2002: 109, 200).

Even if Hemingway's safari suggests his pursuit of personal fulfillment, this safari demonstrates exploration and discovery in Africa in political terms. Hemingway narrates that "I would come back to Africa but not to make a living from it", and then he describes his profession as a writer who uses "two pencils and a few hundred sheets" to reflect on his experiences as a writer, escaping from a 
society where he does not feel at home (2002: 201). Hemingway is therefore far from being considered a mere adventurer and explorer. His reflections on his African experience are highly politicized and his intentions should be suspected and questioned by raising the question: what is he really looking for, and whether he is serving his government's secret designs. This narration makes it safe to read Hemingway through a postcolonial lens. Edward Said argues that Orientalists, who might be expatriates, adventurers, explorers and merchants, are involved in the politics of their countries and they are "constrained in what they could either experience of or say" (1978: 43). According to Said, Orientalism was ultimately a political vision of reality that serves the interests of imperial powers whose domination was facilitated by the large body of textual (and non-textual) representation of these adventurers and explorers who depicted the places they visited as "place[s] of romance, exotic beings, haunting memories and landscapes, remarkable experience" (Said, 1978: 1). Thus, Hemingway can be described as an Orientalist who writes as he travels in Africa to invest in his sojourn and returns with something communicable to Western countries and governments.

The focus in this memoir is on what Said called "Oriental residence and Scholarship". Said argues that Western explorers and adventurers lived in the places they visited "a privileged life, not of an ordinary citizen", but as representative agents to their imperial countries that construct the "Orient in its military, economic, and above all, cultural arms" (1978: 156). Their privileged life carried political and economic significance, and they presented themselves as culturally superior. That is, their residence served their imperial countries at economic, military and cultural levels. The scholarly fruits of this residence "are thereby fed into the bookish tradition of the textual attitudes" (1978: 156-7). Hemingway introduces himself in his works as an explorer and adventurer who has spent some time learning about African people and culture before returning as a victorious general. The victory is at least textual in the sense that he writes and publishes a book in his foreign language to teach something new about Africans. Green Hills of Africa implies that the purposes of Hemingway's adventure and exploration in Africa are greater than being personal; they contribute to the textual misrepresentations of African culture and people in ways described by Said as "a metamorphosis from personal to official statement" (1978:157). He, for example, describes Africa as "dry, sandy, bush-bordered prairies that dried into a typical desert country with occasional patches of bush where there was water" (2002: 115). Thus, Hemingway contributed in his textual testimony/memoir to the large body of literature that served the interests of colonial powers by writing about Africa from a limited and manipulated perspective.

We sense in this narrative the celebratory tone of a white male hunter in Africa. As Armengol argues, "these men repeatedly resorted to the idea of 'civilization' in order to explain male supremacy in terms of white racial dominance" (2011: 75). One can easily notice that the writer contrasts civilized white men with savage dark-skinned men. Green Hills of Africa provides stereotypical and orientalist images of blackness in a manner that involves "quick and easy image", which Toni Morrison called "economy of stereotype", a manner 
that lacks specificity and accuracy (1992: 58). Both Hemingway and his wife describe African people as "savages" (2002: 119), and he describes the Masai people of northern Kenya as "sullen" and "contemptuous" (2002: 115). This description recalls the writings of early settlers in America. John Smith, for example, described Native Americans as "barbarians" and "savages" (2006: 46, 25). This is to suggest that American writing and history can be described as distinctly colonial, beginning from the colonial era until the modern period, wherein the textual inputs of each era has contributed to the era that came after it.

African people in Green Hills of Africa are nameless, that is, their identity is negated. They are referred to as "they" or "the natives" (2002: 29, 32). Even when some Africans are named such as Kamau, the person who carries the name is not described as important. For example, when Kamau nearly dies of fever, Hemingway expresses that if Kamau dies, this means nothing to him except that he would be short of a driver (2002: 129-130). What is significant here is not the person, but his occupation. The name here derives its significance from the work its bearer has. By contrast, the names of white characters are worth mentioning since they represent civilization and progress. The Africans are also described in the memoir as naked savages (2002: 119). This nakedness is associated in the memoir with primitivism, savagery and most importantly inferiority. The memoir suggests that white people are superior to the underdeveloped black Africans who have not known clothes which is seen as a cultural emblem. The naked Droopy is taken for "a real savage" (2002: 40). Hemingway also depicts that two of the local guides were "quite naked" (2002: 116), just as he makes sure to describe the nakedness of the Roman, another native hunter, who "was running naked...crashing naked through the brush" (2002: 168). In his seminal essay 'Are Clothes Modern?', Bernard Rudofsky argues that nakedness has been associated with incompleteness and shamefulness, and he states that "we do not blush to affirm that man without clothes is ludicrous, nor that he is inferior to the equally unclothed but inoffensive animal" (1947: 17). Nakedness in this context suggests weakness, lack of shame, lack of power and lack of moral and manners. This image resonates with Conrad's depiction of naked Africans as people who are "mostly black and naked, moved about like ants" (1990: 12). This makes Africa in Hemingway's memoir a "prehistoric earth", in Conrad's words, which has not yet been named, or introduced to civilization and culture (1990: 31).

Africans are described as people who are in desperate need for education and progress. The lack of education and progress is associated with dirt. Hemingway associates a Wanderobo hunter with "strong odor" (2002: 149). As Fanon suggests, the black person should be dirty because he should be the opposite of the white, "for not only must the black man be black; he must be black in relation to the white man" (1952: 90). For Fanon, this racial difference is necessary for self-recognition since this recognition informs Western feeling of superiority. According to Fanon, this superiority has sustained colonialist attitude towards the orient. One can extend these arguments by drawing on Said's point that the Orient and the Occident have been seen as binary opposites, a binary that has justified colonialism. The Orient, which is seen as passive and dependent has to be feminine, so that the Occident 
which is seen as energetic and independent could be masculine, and this interprets why Africa is depicted as a space waiting to be conquered and appropriated by masculine power.

In his safaris, Hemingway has contributed to textual appropriation of Africa. As stated earlier, this memoir can be read as an extension from Nineteenth-century US and European travel books about the orient. The travels of nineteenth-century US writers to Africa informed some of the most popular US literary works. Placing Hemingway in this historical context enables the reader to recognize the ways in which aesthetic production had to meet the political and colonial demands of the time. Analyzing Green Hills of Africa against this backdrop helps us understand the ways in which Hemingway's textual construction of Africa has consolidated the empire. For Said, even the most imaginative and comic of writers were constrained in what they could either experience or say about the Orient. Said (2006: 9) introduced the phrase "political knowledge" to describe how some travel works about the Orient in the nineteenth century were put into the service of political and colonial powers. Africa is spoken for, it is represented as the other; African history is reconstructed and reinvented in ways that serve the Western superior attitude. For instance, the Austrian guy says that "to me it is always interesting. The natives and the language. I have many books of notes on them. Then too, in reality, I am a king here. It is very pleasant". Then, he asks his interlocutor to promise him that when they come next time "they must take a safari to study the natives" (2002: 21). As such, Green Hills of Africa projects the image of Africa as a place to be discovered and explored, and it is the responsibility of the White man to civilize the Africans. Therefore, the West posits itself as responsible for advancing the East at the intellectual and human level - what is called the white man's burden and mission to transform Africans from darkness into light. This discourse involves both power and imperialist nostalgia as Roslado argues (1989: 108).

\section{Imperialist nostalgia}

One important subject in this memoir is the nostalgic feeling that the narrator has for the green hills of Africa in which he had lived for more than nine months. The social critic Raymond Williams argues that nostalgias mean quite different things under different contexts and different historical circumstances (1975: 12). The historical circumstances out of which this memoir emerged, and the historical implications the text embeds, inform my argument that the form of nostalgia the narrator has is an imperialist nostalgia. Roslado defines imperialist nostalgia as "found under imperialism, where people mourn the passing of what they themselves have transformed" (1989: 108). Hemingway implies in his text that the US imperialism has played a significant role in Africa, and he reflects on this rhetoric towards the end of his memoir when he narrates that the Indian worked so hard and was "ruined by ... making money", while "a white hunter worked three months out of the year and drank for twelve and the Government was ruining the country", claiming that this is "for the benefit of the Hindu and the natives" (2002: 200). This quotation refers to a mission - the white man's mission - through which Western colonial powers colonized and imperialized Africa. Hemingway finds a striking 
similarity between this mission in Africa and the white man's mission in America, and this triggers his nostalgia for pre-colonial American wilderness. Hemingway's narrator laments that "our people went to America because that was the place to go then. It had been a good country and we had made a bloody mess of it" (2002: 201). Hemingway seems to argue that the colonization of America by the Western powers caused a destruction of nature. Frederick Jackson Turner opens The Frontier in American History with the following words: "American history has been in large degree the history of the colonization of the Great West. The existence of an area of free land, its continuous recession, and the advance of American settlement westward, explain American development" (1893: 1). Interestingly, Hemingway applies this rhetoric to his experience in the green hills of Africa "a country was made to be as we found it. We are the intruders and after we are dead we may have ruined it but it will still be there and we don't know what the next changes are" (2002: 201). Again, this is an imperialist nostalgia. Roslado defines it as "some deliberately alters a form of life and then regrets that things have not remained as they were prior to his or her intervention" (1989: 108). While travelling and hunting animals in Africa, Hemingway prophecies changes to it in the future, provided that part of Africa was still under the British control at the time.

Underpinning Hemingway's intervention is a discourse and a systematic discipline by which the colonialist and imperialist culture was able to reproduce Africa and its history politically, sociologically, ideologically and imaginatively. Africa thus seemed essentially an idea or a creation with no corresponding reality. This landscape is thus transformed and reconstructed and its people are re-made, and given assigned roles. The attempt to reconstruct Africa is necessarily an attempt to further rewrite it and its history. As Said reminds us, "history is made by men and women, just as it can also be unmade and re-written, always with various silences and elisions, always with shapes imposed and disfigurements tolerated" (2006: xviii). Hemingway asserts that this country will be transformed. That is why Hemingway's narrator seems to be concerned about nature. He narrates that "the natives live in harmony with it. But the foreigner destroys, cuts down the trees, drains the water" (2002: 200). Colonial shape and disfigurements were imposed on Africa by colonialism. While colonial powers claimed that they have modernized the African landscape and made it inhabitable, Hemingway argues that they have destroyed it. Hemingway in this context subverts the colonial dichotomy that described natives as people who cannot improve the land and colonizers as people who can use its resources for mutual benefits; natives are instead described by Hemingway as protectors of nature because they own it and they have mutual interest with it, and the foreigners are the intruders who alter it.

Hemingway's narrator plays the role of the foreigner in this context. He hunts animals, and thus destroys the ecosystem, but he feels unhappy since he destroys a space he feels he is creating. This is a paradox that again reflects imperialist nostalgia which describes people who "destroy their environment and then worship it" (Roslado, 1989: 108). According to Roslado, this is a kind of mystification. He argues that towards the end of the $19^{\text {th }}$ century Americans had "the attitude of reverence toward the natural developed at the same time that North Americans 
intensified the destruction of their human and natural environment" (1989: 109). This paradox particularly pertains American writing from the $19^{\text {th }}$ century till early $20^{\text {th }}$ century. Modern American authors express an aura of yearning for the natural places and a sense of order, attachment and settlement. At the same time, they feel the necessity of adventure through displacing themselves in the world. Paradoxically, they feel both nostalgic for nature, and therefore express a nativist utopia, and at the same time they feel fully excited and energetic to transform it. Their writing is indeed imbued with a sort of tension between moving forward (centrifugal) and looking back (centripetal) (Qabaha, 2018: 87). Lawrence Levine called this "the central paradox of American history: a belief in progress coupled with a dream of change, an urge towards the inevitable future combined with a longing for the irretrievable past" (cited in Bernard 2005: 45).

The motif of orientation towards nature in modern American literature suggests nostalgia for simplicity and authenticity. This attitude stems from nineteenth-century American writers' glorification of nature. Ralph Waldo Emerson, for example, portrays nature as a source of inspiration for human intellect. Henry David Thoreau's Walden also represents nineteenth-century America's defense of nature against the trappings of industrial modernity (Castronovo, 2012: 394). Broadly speaking, nature in the United States has always been viewed "as a sign of God's beneficent or malevolent design; as a refuge, a place of Edenic simplicity and youthful innocence; as an occasion for introspection, as a source of wealth, as a metaphor for human emotion" (McDonald 2007: 43). However, one should critique the pretended simplicity of Hemingway's narrator when he says "all I want was to live in it and have time to hunt", and he seems to circumvent the sensitive colonial context at the time: "I would come back to Africa but not to make a living from it ... but I would come back to where it pleased me to live; to really live" (2002: 199, 201). One can argue that there is an imperialist tendency in Hemingway's travel to Africa. According to Rosaldo, "imperialist nostalgia uses a pose of 'innocent yearning' both to capture people's imaginations and to conceal its complicity with often brutal domination" - this is the mechanism of imperialism or neo-imperialism (1989: 108). While Hemingway seems to disentangle himself from the rhetoric of the empire, he seems to be involved in it. Hemingway is a colonial official who participated in wars world powers fought in order to consolidate their colonial grip and expand their domination.

Hemingway's nostalgia to live in Africa is really problematic. This kind of nostalgia, according to Rosaldo, transforms "the responsible colonial agent into an innocent bystander" (1989: 108). Hemingway presents himself in this memoir as someone who accounts for the consequences of colonialism and imperialism in Africa and who can anticipate their destructive power, but he undermines the politics of his travel and hunting there. The American historian Richard Slotkin suggests that

the frontier mythology in part revolves around a hunter hero who lives out his dreams in spiritual sympathy with the creatures of the wilderness who teach him their secret lore... but his intension is always to use the acquired skill against 
the teachers, to kill or assert his dominance over them. The consummation of his hunting quest in the killing of the quarry confirms him in his new and higher character and gives him full possession of the powers of the wilderness (cited in Rosaldo, 1989: 109).

This reminds us of the politics of the westward expansion and the imperialist tendency of modern America. The narrator expresses that "I loved this country and I felt at home and where a man feels at home, outside of where he's born, is where he's meant to go" (2002: 200). Hemingway's narrator lived in harmony with people in Africa, and he travelled with them around the country, but he showed a certain kind of superiority and power, even intimidation. Although Hemingway occasionally confesses that his representation of blackness is stereotypical and driven by racial difference, his writing clearly states that Africa is a place beyond the borders of civilization and progress.

\section{Conclusion}

This article has provided a thorough and critical analysis of Hemingway's Green Hills of Africa. By engaging with postcolonial theory and recent critiques of Western travelogues about the Third world, especially Hemingway's oeuvre, this article has argued that Hemingway's memoir reflects an orientalist and colonialist rhetoric that informed literary scholarship during the $1^{\text {st }}$ half of the twentieth century. The article has illustrated that Hemingway's reflections on Africa and its people during his safaris seems to have been influenced by $19^{\text {th }}$ and early 20th Western, especially British, authors whose textual and imaginative representations of Africa, whether consciously or unconsciously, consolidated imperial authority. This article has further explained that although Hemingway's text seems to show a sympathetic attitude towards the colonized, he endorses the imperial patronage and does not seriously question the legitimacy of British colonialism.

This article was divided into two sections, each of which has a major subargument. The first section of this article has demonstrated that Hemingway considers Africa an alternative home away from America and Europe. Africa looks in the memoir a site of performing and experimenting a new identity or an exotic space wherein the author projects his fantasies and conflicts. Hemingway's commentaries relegate African people to an inferior status, while viewing them as people who are in need of Western progress and advancement. The second section of this article questions the politics of Hemingway's nostalgia for the green hills of Africa. This article has argued that the protagonist's nostalgia can be classified as an imperialist nostalgia that accounts for the effects and legacies of Western imperialism across ages.

Ahmad Qabaha

An-Najah National University, Palestine

ORCID Number: 0000-0001-7378-0683

Email: aqabaha@najah.edu 


\section{References}

Armengol, Josep. (2011). 'Race-ing Hemingway: Revisions of masculinity and/as whiteness in Ernest Hemingway's Green Hills of Africa and Under Kilimanjaro'. The Hemingway Review, 31(1): 43-61.

Boehmer, Elleke. (2005). Colonial and postcolonial literature: Migrant metaphors. Oxford: OUP.

Barnard, Rita. (2005). 'Modern American fiction'. In Walter Kalaidjian (Ed.), The cambridge companion to American modernism, 39-67. Cambridge: Cambridge University Press.

Clifford, James and George Marcus (1986). Writing culture: The poetics and politics of ethnography. California: University of California Press.

Conrad, Joseph. (1990). Heart of darkness. North Chelmsford: Courier Corporation.

Castronovo, Russ. (2012). The Oxford handbook of nineteenth-century American literature. Oxford: OUP.

Cresswell, Tim. (2001). The tramp in America. Edinburgh: Reaktion Books. Droze, Brent. (2018). 'The lasting legacy of American colonization in Africa'. The Justice Lab - A critical Analysis for Justice. Place of publication, publisher and page numbers?

Fanon, Frantz. (1952). Black skin, white masks. London: Pluto Press.

Fantina, Richard. (2005). Ernest Hemingway: Machismo and masochism. London: Palgrave Macmillan.

Gregory, Derek. (2004). The colonial present: Afghanistan, Palestine, Iraq. London: Blackwell.

Hemingway, Ernest. (2002). Green Hills of Africa. New York: Simon and Schuster.

---. (2005). Under Kilimanjaro. Kent: Kent State University Press.

Levin, Harry. (1970). 'Introduction', ix - xx. In Williams, C. William. A voyage to Pagany. New York City: New Directions.

Melling, Philip. (2006). 'Cultural imperialism, Afro-Cuban religion, and Santiago's failure in The Old Man and the Sea'. The Hemingway Review 26 (1): 6 24.

Morrison, Toni. (1992). Playing in the dark: Whiteness and the literary imagination. Harvard: Harvard University Press.

Parsons, Deborah. (2000). Streetwalking the metropolis: Women, the city and modernity. Oxford: Oxford University Press.

Qabaha, Ahmad. (2018). Exile and expatriation in modern American and Palestinian writing. London: Palgrave Macmillan.

---. (2019). 'Decolonizing history and depoliticizing territory: Raja Shehadeh's Palestinian walks: Notes on a vanishing landscape'. Interventions 21 (7): 1030 - 1044.

Parsons, Deborah. (2000). Streetwalking the metropolis: Women, the city and modernity. Oxford: Oxford University Press. 
Reynolds, Guy. (2008). Apostles of modernity: American writers in the age of development. Nebraska: University of Nebraska Press.

Roslado, Renato. (1989). 'Imperialist nostalgia'. Representations 26, 107 -122.

Rudofsky, Bernard. (1947). Are clothes modern?: An essay on contemporary apparel. Chicago: Paul Theobold.

Said, Edward. (1983). The World, The Text and The Critic. Harvard: Harvard UP. ---. (2006). Orientalism. London: Penguin Books.

Smith, John. (2006). The Generall historie of Virginia, New-England, and the Summer Isles. Carlisle, Massachusetts: Applewood Books.

Spurr, David. (1993). The Rhetoric of empire: Colonial discourse in journalism, travel writing, and imperialist administration. Edinburgh: Duke University Press.

Turner, J. Frederick. (1893). The Frontier in American history. Florida: Krieger Pub. Company.

Mandel, Miriam. (2011). Hemingway and Africa. London: Camden House.

McDonald, Gail. (2007). American literature and culture, 1900-1960. London: Blackwell Pub.

Williams, Raymond. (1975). The Country and the city. Oxford: Oxford University Press. 